\title{
Reformed theology and 'decolonised' identity. Finding a grammar for peaceful coexistence
}

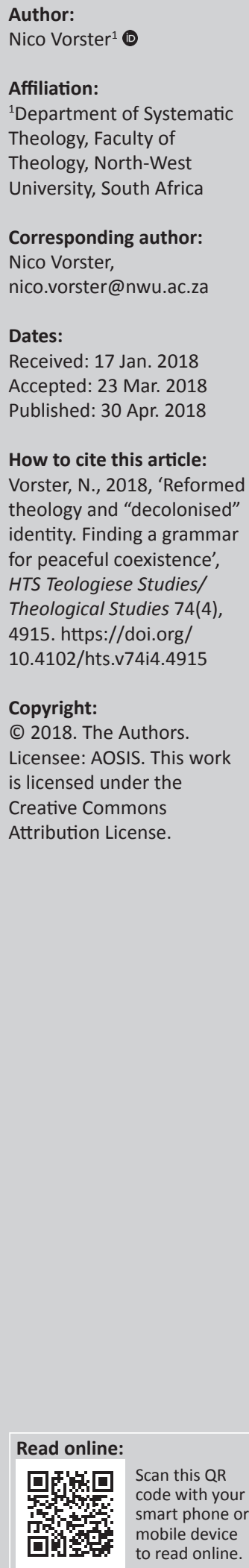

\begin{abstract}
Decolonisation discourse has gained significant momentum in South Africa with the rise of the various \#MustFall movements that strive to rid South Africa of its colonial vestiges. But does South Africa need another national metanarrative that envisions an ideal South Africa and champions utopian social ideals? Following the logic of Johan Degenaar and Dirkie Smit, this contribution argues that we should refrain from developing social meta-narratives that seek to frame a single South African identity and social ethos. However, we do need a grammar for peaceful coexistence that goes beyond legal and procedural considerations to establish basic parameters for a constructive social discourse that promotes peaceful coexistence. Such a grammar cannot be imposed unilaterally on social groupings but should be framed by a public discussion aimed at reaching a consensus among social imaginaries on the rules of discourse. Drawing on Reformed thinkers such as John Calvin and John Althusius, the essay continues to discuss the contribution that the Reformed tradition can make to such a grammar. The last part of the essay proceeds to apply the proposed grammar as a benchmark to evaluate the validity of decolonisation discourse.
\end{abstract}

\section{Introduction}

Since the inception of the South African democratic state in 1994, various attempts have been made to frame a collective South African identity that would unite South Africans behind a single social ethos and give direction to the shaping of a new society. A polyphony of public discourses, all outlining their own visions of the ideal post-Apartheid society, has coexisted in the South African public domain since 1994. Some narratives operated on the fringes and never attained wide social acceptance, while others dominated certain phases of post-Apartheid South Africa but faded as South African public discourse evolved. The Mandela-era (1994-1998), for instance, was dominated by the 'rainbow' narrative that emphasised the need for reconciliation and unity amidst diversity. Popularised by Desmond Tutu and Nelson Mandela, the 'rainbow' narrative promoted a collective South African identity where plural identities 'converge in the singular' (Brunsdon 2017:4). Central to the discourse was the notion of nation-building; the moral frameworks of Western human rights discourse and ubuntu; the reconciliation efforts of the Truth and Reconciliation Commission, the ideal of non-racialism; and the neo-liberal quest for quick economic growth.

The 'rainbow' narrative was soon challenged by demands for greater social justice and more drastic efforts to implement transformation. The State had to keep racial classification alive to enforce affirmative action programmes; the individualist nature of Western human rights discourse collided with egalitarian and communalist African worldviews; and neo-liberal economic policy did not yield a sufficient trickle-down growth effect, nor did it agree with the socialist beliefs that were historically part and parcel of African nationalist identity.

Thabo Mbeki's 1996 I am an African address before the South African Constitutional Assembly and his 1998 Two Nations speech during the opening of Parliament challenged the idealism of the 'Rainbow' narrative. In his infamous Two Nations speech Mbeki stated:

South Africa is a country of two nations... One is white, relatively prosperous, regardless of gender or
geographic dispersal. It has ready access to a developed economic, physical, educational, communication
and other infrastructure. The second and larger nation of Africa is Black and poor ... This nation lives
under conditions of a grossly underdeveloped economic, physical, educational, communication and other
infrastructure. It has virtually no possibility to exercise what in reality amounts to a theoretic right to
equality. (As quoted in Ansell 2004:4-5)

Whereas the 'rainbow' narrative embraced Western notions of a universal human identity that transcends all racial and cultural boundaries, the Mbeki administration searched after the 
'Africanisation' of South African identity. Mbeki articulated his vision through the term 'African Renaissance', which called for the rebirth of the African continent through the renewal and democratisation of political systems in Africa and the reordering of the global economic order so that the interests of the poor can become part of the global agenda (see Vorster 2017:45). Underlying his Renaissance concept was Mbeki's resistance to what he perceived as the neoimperial and neo-colonial nature of the global order. Not surprisingly, public policy during the Mbeki era exhibited a shift away from reconciliation discourse to social justice speech and from a nation-building agenda to a more intensive social transformation and black empowerment programme. With the demise of the Mbeki government in 2007, the 'African Renaissance' narrative lost some impetus. Mbeki's concerns with the global order seemed far removed from the daily afflictions that ordinary South Africans faced, while his affirmation of liberal economic policy and views on the need for the modernisation of African economies and governance systems encountered stark resistance from the socialistminded alliance partners within the African National Congress (ANC), such as Cosatu and the South African Communist Party.

Recently, South Africa has witnessed the rise of what Gibson terms 'the latest disillusion with rainbow politics' (2017:579). Rising unemployment, political corruption, the perpetuation of inequality and low economic growth under the Zuma administration has upended the hopes and aspirations of especially the black youth. Mbembe (2015b) notes that 'anger, rage and muted grief' have become the 'new markers of identity and agency'. He proceeds to state:

Rainbowism and its most important articles of faith - truth, reconciliation and forgiveness - is[sic] fading. Reduced to a totemic commodity figure mostly designed to assuage whites' fears, Nelson Mandela himself is on trial. Some of the key pillars of the 1994 dispensation - a constitutional democracy, a market society, non-racialism - are also under scrutiny. (Mbembe 2015b)

'Decolonisation' discourse has gained significant momentum among younger blacks since the \#RhodesMustFall and \#FeesMustFall student protests of 2016. The basic claim of the \#Fall movements is that the political rights that black people gained during the transition to a democratic system have not translated into economic empowerment. To rectify this, the student movements demand free education, the decolonisation of curricula, the cancellation of student debt and the 'insourcing' of workers to deliver basic services at universities (Gibson 2017:586). The protests opened up a large-scale national debate on decolonisation that invoked and discussed the works of Frantz Fanon and Steve Biko. While their views have always been influential within black consciousness circles in South Africa, it never enjoyed 'mainstream' support. Yet, as the recent proliferation of academic literature on decolonisation philosophy illustrates and as emotionally charged public calls for the 'decolonisation' of education curricula and the economy indicate, this state of affairs may be changing. In December 2017, President Jacob
Zuma announced free higher education for all students from poor backgrounds, while the National Elective Conference of the ruling ANC resolved to decolonise education curricula. Achille Mbembe (2015b) encapsulates the shift in the South African social imaginary well when he states that 'a new cultural temperament is gradually engulfing post-apartheid urban South Africa. For the time being it goes by the name of decolonisation'.

But does South Africa need a discourse that frames yet another collective concept of South African identity? Do we need a national identity at all? Are efforts to create an allembracing philosophical and moral discourse not merely a disguised effort to exert social power? During the transition period of the 1990s, the South African philosopher Johan Degenaar warned against attempts to articulate collective notions of nationhood and nation-building. He considered such notions as myths that 'absolutise the sovereignty of the people' and 'submerge individual citizens in a collective personality' (As quoted in Smit 2017:65). Following Degenaar's argument, Dirkie Smit claims that the social tensions in South African civil society have their 'roots' precisely in the contestations that emerge when various groups try to impose their social imaginaries, visions of the ideal South Africa and concepts of the common good on broader society. When a specific collective national identity is championed, the common good tends to be construed as whatever contributes to the particular vision of national identity (Smit 2017:67). The result, according to Smit, is that 'all kinds of public institutions, private sector actors as well as social movements and associations are continuously judged by whether they serve this national ideal or not' (Smit 2017:67).

This contribution supports the basic premise of Degenaar and Smit. Expansive national projects that attempt to develop a collective sense of nationhood are not plausible in plural societies, and certainly not in a society as culturally, religiously and politically diverse as South Africa. Like most modern societies, South Africa is characterised by a multitude of secular, Christian, Muslim, Jewish, Hindu, Buddhist, African, Pan-African, postcolonial, neo-liberal, sociodemocratic, liberal democratic, socialist and communist social imaginaries that are grounded in a wide range of ultimate loyalties, self-understandings, moral doctrines, anthropologies and social philosophies. These imaginaries not only diverge from each other but are often internally fragmented. The search for a comprehensive collective national identity therefore risks fuelling a Machiavellian race between opposing imaginaries who all want to control national discourse.

Dispensing with collective national ideals is simple enough, but the question begs: How can a plurality of discourses and social imaginaries that contain their own conceptions of the common good coexist in a peaceful manner? Degenaar rightly argues that the best South Africa could hope for is to develop a basic grammar and democratic institutional culture 
for living together peacefully (Smit 2017:64-65). Building on Degenaar and Smit's argument, this essay argues that, instead of creating comprehensive visions of the ideal South Africa and engaging in struggles for the soul of the nation, we ought to find a grammar that sets parameters for social discourse within which a plurality of social imaginaries can coexist, interact and disagree without resorting to violence, coercion or power abuse. Admittedly, the South African Constitution sets a valuable legal and procedural framework within which public discourse can operate. However, public discourse cannot be guided by constitutionalism alone. While the Constitution and the courts are important tools in adjudicating and enforcing basic rights, they have a legal mandate and are not equipped to engender a meaningful social discourse that brings about progress. This task belongs to the citizens of South Africa. We need a national dialogue on a grammar of social discourse that provides us with a benchmark to assess the validity of social imaginaries and guides us in the manner in which we engage with each other.

Admittedly, freedom of speech should be respected within the ambits of the law and people should be allowed to speak their minds without fear of being persecuted. But this does not mean that all discourses in South African society ought to be recognised as morally legitimate, valid or as meaningful enough to be listened to it. A basic set of discursive norms, a minimum consensus on the rules of the game, is needed to make social discourse worthwhile and to generate meaningful interaction. If such parameters are not set, and all narratives are simply recognised as legitimate or worthy of respect, social discourse risks being captured by movements who are not interested in constructive engagement but seek platforms to exert coercive power.

Developing an appropriate grammar of social discourse requires that social imaginaries explore the positive resources within their traditions and bring their unique perspectives on what such a grammar entails to the table. In what follows, I provide a short Reformed perspective on such a grammar. My aim is to present a grammar that other comprehensive social doctrines may find intelligible and universal enough to engage with. Thereafter, I proceed to engage with decolonisation discourse and indicate why I think that certain strands of decolonisation theory are important to listen to, and why others ought to be rejected as invalid because they do not conform to a basic moral grammar of peaceful coexistence.

\section{A reformed grammar for peaceful coexistence}

Conversation partners may ask: Why a Reformed grammar? My response is that Reformed social thought has always shown a particular interest in the public relevance of theology by reflecting on the social import of theological themes such as the sovereignty of God, creation, natural law, the kingdom of God, common grace, vocation, justification and sanctification. These perspectives are worthy of consideration.
That said, the aim of this article is not to present an exhaustive theological basis for my argument but only to identify some basic themes within the Reformed tradition that could be helpful in developing an overlapping consensus ${ }^{1}$ on a basic grammar for constructive social discourse and peaceful coexistence within a highly diverse society. In doing so, I do not argue that the Reformed tradition provides the only avenues to such a grammar. In fact, other traditions such as the Catholic common good tradition, Marxist social analysis and liberal rights discourse have made enduring and very important contributions to social and political thought. Neither do I suggest that Reformed social thought presents a homogeneous tradition, as a variety of models have been offered within this 500-year-old tradition for understanding the relationship between society and religion. Here we can only mention the natural law theories of Francois Turretin, the two-kingdoms approach of John Calvin, the covenantal and social compact philosophies of John Althusius and the Puritans, Abraham Kuyper's Neo-Calvinist theory and Arnold Van Ruler's theocratic perspective. Lastly, I do not claim that all Reformed societal doctrines are applicable to a modern pluralistic South Africa. Sixteenth century-type theocratic approaches, for instance, are not viable in modern societies.

Four themes found in Reformed social thought might be helpful in developing a basic grammar of social discourse and peaceful coexistence. These are the recognition of universal dignity of all people, respect for the symbiotic and associational nature of human existence, the commitment to truth-seeking and the understanding that continuous social reform is important.

Most reasonable social traditions will accept the principle of universal dignity of all people, although they ground their understandings in different moral philosophies and anthropologies. Reformed theology largely bases the dignity and rights of human beings on their createdness in the image of God. Although Reformed theology maintains the depravity of all people, it also insists that sin does not dehumanise human beings. Despite being corrupted by sin, all human beings possess the image of God, and they therefore ought to respect their neighbours as creatures of God. Calvin states it aptly:

But I say that the whole human race, without exception, are[sic] to be embraced by one feeling of charity: that there is no distinction of Greek or Barbarian, worthy or unworthy, friend or foe, since all are to be viewed not in themselves, but in God. (Institutes 2.8.55)

The unconditional acceptance of the universal dignity of all human beings is vital, not only to legal discourse but also to

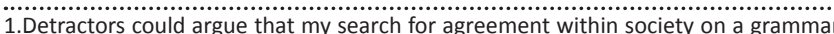
of social discourse and peaceful coexistence is relativist in nature and compromises of social discourse and peaceful coexistence is relativist in nature and compromises the truth claims of Reformed theology. My response is that the imposition of theocratic or theonomous ideals on society are not desirable because authentic faith commitments are brought about by persuasion, not coercion. They are also not viable because modern societies comprise a wide range of groups, faiths and moral commitments. At the same time, I reject the secular-humanist notion of the public realm as a neutral space reserved for 'rational' social imaginaries. Socia imaginaries ought to be allowed to engage with each other without them being expected to hide their views in neutral talk. 
all public discourse. A grammar of constructive social discourse and peaceful coexistence is only possible when the innate equal worth of partners in conversation is accepted from the start. Respect for universal dignity does not require that participants relinquish their own conceptions of truth or accept all discourses or worldviews as of equal value, nor does it imply that we refrain from challenging and opposing the arguments of others. However, it does require a basic respect for and recognition of the humaneness of the other and the right of the other to be treated with respect. Overt racialist discourse that uses somatic norms to posit the inherent superiority of some races and cultures above others would therefore not satisfy the basic conditions for the grammar we propose. Racialist worldviews may be tolerated, at best, as long as they do not pose physical harm to others, but they should not be recognised as valid or reasonable or worthy of public consideration. The same applies to religious extremist narratives that portray those who do not share their worldviews as evil and unworthy of respect. Valid discourse requires the recognition of the humaneness of the other. Without recognition of the other, no discourse is possible or sustainable.

Closely related to the principle of the universal dignity of all people, is the recognition that human existence is symbiotic and associational by nature. The Reformed political philosopher, John Althusius (1557-1638), describes politics as symbiotics (1964:17). For Althusius (1964), politics is not in the first place about the exercise of power, but it concerns the art of associating:

Politics is the art of associating (consociandi) for the purpose of establishing, cultivating and conserving social life among them. Whence it is called 'symbiotics'. The subject matter of politics is therefore association (consociatio), in which the symbiotes pledge themselves each to the other, by explicit or tacit agreement, to mutual communication of whatever is useful and necessary. (p. 17)

The notion of politics as symbiotics holds that human beings are not self-sufficient beings but are created as interdependent beings that should associate with each other to survive. Politics is about gift exchange. We need each other's unique skillsets and perspectives to flourish. Althusius (1964:8-10) held that associations enable us to distribute rights, things and services that are useful and necessary. Because viable and sustainable associations cannot be formed through violence and aggression, Althusius maintained that associational formations require a spirit of mutual help and non-aggression (see Ossewaarde 2007:111-113). Following Althusius, we can state that an authentic social grammar that makes a peaceful coexistence possible recognises the other as important for a person's own cause because the individual cannot exist in a harsh, challenging and complex environment without associating with others. Association requires on the one hand that we adopt an attitude of non-aggression and cooperation towards the other and offer our unique skillsets to the other. Conversely, it demands that we exhibit an openness to the possibility that other worldviews may enrich, correct or alter our outlook profoundly.
A third condition for a grammar of constructive discourse and peaceful coexistence in my view is a shared commitment to truth-seeking. The Reformation's allegiance to the sound exegesis of Scripture, its efforts to rediscover the wisdom of classical sources and its affirmation of the importance of the natural sciences and education was kindled by a search for truth. When referring to truth-seeking within public discourse, we are not speaking about a particular methodology or comprehensive metanarrative but about authenticity; that is, an attitude characterised by a genuine commitment to credible, fair, reasonable and honest discourse. When parties share a commitment to truthfulness, they will also display a willingness to alter their perspectives when confronted with persuasive evidence. Unfortunately, not all social groupings participate in social discourse for the right reasons. Social imaginaries that deliberately distort reality and invent falsehoods in order to exact social control are not worthy of being considered as valid discourses because they are interested in power, not truth-in coercion, not solutions. Sustainable solutions and authentic coexistence are only possible as long as truth is respected as the most fundamental ingredient of dialogue.

The last principle I propose for a social grammar is the Reformed notion of semper Reformanda. The magisterial Reformers held that human beings as stewards of God have the calling to continuously renew and reform society according to God's original creational purposes. This specifically entails that social discourse should seek social justice. Social justice entails, in my view, that we acknowledge the equal rights of all people, and the importance for society to distribute social goods fairly. Social reforms are continuously needed, because societies are always under threat of being penetrated by new forms of injustice. The search for social justice, however, does not justify the use of violence as a means to an end. The rationale of constructive social discourse, after all, is to provide a form of conflict resolution that does not engage in violence. The Reformers were careful not to widen the ambit of Christian liberty to justify anarchy or violence. Calvin (1847:36), for instance, maintained against the Anabaptists that penultimate reality should not be confused with ultimate reality and that eschatological arguments should not be used to subvert the temporal social order. Calvin (Inst. 3.19.15) states it as follows:

There exists in man a kind of two worlds, over which different kings and different laws can preside. By attending to this distinction, we will not erroneously transfer the doctrine of the Gospel concerning spiritual liberty to civil order, as if in regard to external government Christians were less subject to human laws, because their consciences are unbound before God.

It follows that although the Reformers subscribed to the need for self-correction, change and social transformation, they did not recognise violent acts and anarchy as legitimate means to bring about change, because such actions give an ultimate status to a reality that is temporal. Calvin, in fact, did not even allow for the violent overthrow of tyrannical governments (Inst 4.20.25-26). 
The social grammar that I propose, then, is based on ontology of peace and an attitude of non-aggression. It does not allow for discourse that threatens to subvert the social order through violent means. Using threats of violence or anarchy to force opponents to accept a particular outcome amounts to blackmail and contradicts the very idea of discourse and dialogue. Authentic discourses aim at persuasion, not coercion or intimidation. Violence is in itself a form of injustice.

Having provided a short outline of what a basic grammar for constructive social discourse and peaceful coexistence entails, I now turn to the decolonisation narrative. My intention is to use the proposed grammar as a benchmark to assess the validity of decolonisation discourse.

\section{Assessing decolonisation discourse}

Decolonisation philosophy signifies a broad and rather fluid discourse that reacts to the perpetuation of colonialist structures in postcolonial societies and calls for the establishment of a collective postcolonial identity that is embedded in African experiences and needs. The discourse finds its historical impetus in the works of Frantz Fanon, who explored the ways in which colonised people internalised the image that others bestowed on them and uncritically adopted the worldviews, values and historical narratives of Western colonial powers (Wisker 2007:185). Building on the theories of Lacan and Freud, Fanon argued that black people tend to adopt 'a white mask' to conform to the values of the white elite and to enter dominant culture. By doing so, they destroy their own African identities (see Wisker 2007:185-186). Steve Biko popularised the thoughts of Fanon in South Africa by establishing the black consciousness movement. According to Gibson (2017:580), Biko found in Fanon 'an important interlocutor to think about internalised inferiority and liberation, the notion of black not in relation to white, but as an attitude of mind that begins with itself'.

Building on themes in the thoughts of Fanon and Biko, postApartheid decolonisation discourse is generally concerned with African self-emancipation; developing an African epistemology; identifying the ways in which Western concepts are assimilated into African thought through the imposition of foreign languages; resisting the universalist claims of Western discourse; and challenging instrumentalist forms of rationality and addressing economic inequality. Much emphasis is placed on the importance of social praxis, participatory discourse, lived experience, the deconstruction of the so-called colonialist attitudes and the rights of the marginalised and vulnerable.

Contrary to general perception, decolonisation discourse is by no means monolithic but is marked by both militant and moderate strands. The militant strand regards violent action as 'the real measure of decolonization' (Gibson 2017:586) and calls for the complete 'subversion' and 'destruction' of colonial attitudes, concepts and scientific discourse (Carman 2016:235-236). They hold that education curricula ought to include African-based knowledge paradigms only (Etieyibo 2016:405-406). The \#FeesMustFall student movement in South Africa represents such a militant approach. This movement embraces what Mbembe (2015b) calls an 'anti-decorum' ethos by disrupting university activities and defiling or damaging university property. The moderate approach, in contrast, seeks to generate crosscultural dialogue and construct a new African identity by appropriating what is valuable from Western thought and rejecting that which is not relevant to the African experience. Supporters of the militant brand often accuse moderate decolonisation thinkers of employing a restricted understanding of decolonisation and attempting to validate African philosophy in the eyes of the west, while the moderate grouping is critical of the fanatical and violent elements of the radical discourse and the decontextualised and artificial manner in which the thoughts of Fanon are interpreted (see Carman 2016:239; Gibson 2017:588; Johnson 2013). In what follows, I will examine three key features of decolonisation philosophy.

\section{Blackness and whiteness as metaphors}

Integral to decolonisation discourse is the use of black and/ or white metaphors to subvert the pseudo-scientific norms employed by European colonialists who linked somatic features to mental attributes (see Luckett 2016:420). The terminology serves to upend the colonial identification of whiteness with racial superiority and blackness with uncivility. 'Whiteness' represents in decolonisation discourse coloniality, oppression and elitism, while 'blackness' signifies an attitude of mind that is free, non-hierarchical and nonpaternalistic. Coloniality, for its part, is understood as longstanding and global matrices of power that arose as a result of colonialism (see Ndlovu-Gatsheni 2013:331). They shape cultural patterns, self-images and modern experiences and confine black people to the lowest 'echelons' of life (NdlovuGatsheni 2013:333).

By using these metaphors, decolonisation philosophers claim to 'demystify' white notions of racial superiority, while encouraging a black self-consciousness that liberates black people from the inferiority complex that coloniality imposed on them (see Johnson 2013:55, 59; Mbembe 2015a). Decolonialisation discourse is therefore not interested in non-racialist language, because such discourse does not change structures but actually conspires to uphold the status quo (see Gibson 2008:2007).

Is the decolonisation narrative's use of black and/or white metaphors reconcilable with the basic conditions for a grammar of constructive social discourse and peaceful coexistence? Though decolonial philosophers claim that they use the terms 'whiteness' and 'blackness' in a metaphoric sense, it is clear that these terms are often used, at least in popular South African decolonisation discourse, in a binary racial sense, bringing the principles of the universal dignity 
of all people and a commitment to symbiotic existence into jeopardy. Eloff (2017:25) rightly notes that the decolonisation narrative's rejection of non-racialism permits at best a renewed black consciousness and at worst a 'new form of racism'. Mbembe (2015b) also expresses concern about the racial obsessions inherent to current South African social discourse:

'Whiteness', 'white power', white supremacy, 'white monopoly capital' is firmly back on the political and cultural agenda and to be white in South Africa now is to face a new - old kind of trial although with new judges - the so-called 'born-free'.

Decolonisation thinkers may argue that the use of white and/or black metaphors are needed to exact social justice and ensure social reform. Yet, I would argue that the demand of militant decolonisation thinkers for whites to be collectively held accountable for the past is problematic from a social justice point of view, because it works with a concept of guilt and culpability that separates moral accountability from moral agency. When agency and accountability are separated, individuals can be judged as 'unwanted' or guilty simply because of their group association or lineage. Obviously, individuals who engaged in past crimes of humanity, in this case Apartheid, ought to be held accountable for their specific actions. Yet, the logic of a historical or collective culpability for acts that individuals themselves have not committed is not sustainable from a social justice point of view. By stating this, I do not deny that social transformation and restoration is vitally important for the peaceful coexistence of future generations.

The most troubling feature of decolonisation discourses' white and/or black imaginary, in my view, is that it feeds into an unhealthy obsession with 'Whiteness' that becomes, in the words of Mbembe, the 'mirror object of our fear and envy, our hate and attraction, our repulsion and our aspirations' (2015b). In her recent book containing interviews with young black South Africans, Ferrial Haffajee (2015:190) observes that her interviewees assigned a kind of mysterious power to 'whiteness' and white people in South Africa that does not exist in reality. Mbembe (2015a) strikingly encapsulates the danger of this mythic obsession:

Whiteness is at its best when it turns into a myth. It is the most corrosive and the most lethal when it makes us believe that it is everywhere; that everything originates from it and it has no outside.

Ironically, decolonisation discourse seems to be simultaneously shaped and limited by 'whiteness'. The question is: Does the white and/or black imaginary of decolonisation discourse not kindle a 'self-indulgent' victim identity saturated by selfdefinitions of pain and suffering? (see Mbembe 2015:8). Mungwini (2016:526) rightly opines that African thinkers ought to be cautious not to 'always look for reasons outside of ourselves to account for our tragedies'. Once a group defines themselves in terms of being victims of history who inherited a generational curse, they allow themselves to be defined by forces outside themselves and they start to abandon their own ability to steer the course of their lives.
In sum, radical strands of decolonisation discourse, in my view, should do serious introspection on the racial attitudes that underlie their discourse if they are to conform to the basic conditions of a grammar of constructive social discourse and peaceful coexistence. Conversely, we need to state that moderate brands of decolonisation that stay clear from racial abuse while sensitising us to the unique experiences of black people and the challenges they face, make an important contribution in promoting the universal dignity of all people, seeking truth and justice and making a symbiotic coexistence possible.

\section{Africanist epistemology}

Following Fanon (2004:63-64), decolonisation thinkers reject the universalist claims and instrumentalist nature of modernistic Western discourse as paternalistic, as it is deemed as driven by an attempt to control and to silence all other discourses. Instead, decolonisation discourse's focal point is to assert African culture and to enact an epistemic revolution that de-marginalises African epistemologies, divests the African continent from the domination of imperial knowledge systems and promotes a form of knowledge production that satisfies African needs and identity (see Higgs 2012:39; Luckett 2016:422; Mungwini 2016:528). Mungwini (2017:524) describes this epistemological reconfiguration as a process of 'recentring', whereby African thought is de-marginalised and 'theory and praxis is rooted in African experiences'.

In contrast to universalist and instrumentalist discourses, the decolonial mindset is concerned with popular praxis and the lived experience of Africans. 'Lived experience' refers to reality as experienced by Africans. Higgs (2012) defines it as follows:

For Africans, what they know is inseparable from how they know it in the lived experience of their African culture. This sense of Africaness is, in other words, born out of a deep socialethical sense of cultural unity that provides the African identity with its distinctiveness. (p. 50)

The natural question that follows is: When is an intellectual product considered 'African'? Higgs distinguishes between geographical and cultural criteria. The geographical criterion regards a product as African when it is produced by an individual who lives in Africa, while the cultural approach considers a scholarly artefact as African when it displays the 'theoretical and conceptual underpinnings of African culture' and endeavours to address African challenges (Higgs 2012:40, 41). Proper knowledge production is regarded as inclusive and participatory in nature. This entails that researchers engage grassroots communities in their research by recognising them as the primary stakeholders of community research, while the competencies of the community are advanced to produce outcomes that serve the best interests of the community (see Higgs 2012:45).

From the perspective of the aforementioned conditions for a grammar of peaceful existence, moderate decolonisation discourse plays an important role in making us aware of the 
need to recognise the needs, interests and unique contribution of African epistemologies, worldviews and languages to the broader landscape. By doing so, it contributes to a symbiotic culture in South Africa that utilises the diversity of social resources at its disposal to serve the best interests of society. The call for reinventing indigenous African epistemologies should be welcomed as long as it is used, as Mungwini (2016:529) proposes, to promote dialogue between cultures and to enrich collaboration between knowledge systems. Of special importance is the decolonisation narrative's refusal to divide reality in neat realms, such as the sacred and secular realm, spiritual and natural, eternal and temporal. The African worldview's holistic understanding of the interconnected nature of reality and its emphasis on the human being as embedded in nature and as sharing agency with other creatures provide promising avenues to address environmental issues such as global warming and the exploitation of natural resources, while it also provides a foil to excessive individualism and consumerism. Another important contribution of decolonisation thought is its effort to unlock the knowledge generating potential of indigenous languages and the contribution they make to global knowledge. African languages contain a wealth of sayings, proverbs and expressions that are not always easily translatable into dominant languages, yet they contain rich philosophical and religious perspectives on reality, nature and human existence. As language, meaning and knowledge are closely interlinked, the demise of minority languages is akin to the loss of historical treasures and the dignity of social groups. Concerted efforts should therefore be made to rekindle endangered languages. Luckett (2016:421) rightly notes that the hegemony of colonial language in South Africa, despite constitutional guarantees, serves as a severe restraint for the academic success of black students who are expected to study and converse in environments that 'negate' their home languages. A third important contribution of decolonisation discourse is its attempt to read history through the lenses of blacks, slaves and the colonised. Although ideological reconstructions should never be imposed on our reading of history, truth-seeking demands that we acknowledge that history is often written by the powerful and that historiography has many angles and dimensions to it. The silent voices of history ought to be heard and oral transmissions of experiences and events ought to be unlocked if we are to develop credible perspectives on our histories. Lastly, decolonisation philosophy makes an important contribution to education by rethinking community-based research from a bottom-up rather than top-down approach and emphasising the need for education to be relevant to the African context (Van der Westhuizen, Gruel \& Beukes 2017:3-4). Taking the experiences and wants of people at grassroots level into consideration is fundamentally important for generating new knowledge. Having said this, we should reject the notion that knowledge can be democratised and that 'research findings should reflect the voices of the people of South Africa' (Van der Westhuizen et al. 2017:6). Knowledge that is constructed to tell us what we want it to tell us is not credible, has no corrective function and cannot bring about progress.
While recognising the strengths of decolonisation epistemology, it also exhibits various weaknesses that are difficult to reconcile with the basic conditions for a grammar of constructive social discourse and peaceful coexistence. Firstly, the term decolonisation is often deliberately used in a vague and fluid manner. Mbembe (2015b) rightly notes that all sorts of concepts, analogies and metaphors are deliberately blurred by decolonial activists to 'embrace confusion' and upset normal discourse. The essay of Nhemachena, Mlambo and Kaundja (2016), for instance, deliberately mixes up the concepts of time and space by speaking of past colonial practices such as slave trading and medical experiments on Africans as if they are happening at present. No effort is made by the authors to distinguish between past and present. But is the application of such forms of 'conceptual blurring' academically acceptable and ethically defendable? In my view, they do not conform to the basic condition of truthseeking and credibility that is demanded by a grammar of peaceful coexistence.

Closely related to the issue of conceptual truthfulness is the danger that the concept of decolonisation might end up either as a meaningless idiosyncrasy or as an abusive ideology if all social justice issues are simplistically placed under the rubric of decolonisation. Truth-seeking requires that the precise relation between social justice activities and colonial activities of the past ought to be identified and clarified before institutions such as universities embark on wide-ranging decolonisation policies.

Truth-seeking, moreover, demands that intellectuals and opinion makers should not construct distorted images of rival epistemologies or ideologies. Some exponents of decolonisation theory, for example, persist in portraying the Western intellectual tradition as a uniform and undeviating corpus of thought. Mbembe (2015a), for instance, describes the Western tradition as a 'hegemonic' tradition that represses all thought from outside its own parameters. But is this really the case? Surely we ought to recognise that the Western intellectual tradition is comprehensively rich, multi-layered, contradictory, self-contestating and self-corrective in nature. It gave birth to capitalism and socialism; individualism and collectivism; democracy and communism; Machiavellianism and liberalism; slavery and emancipation; modernism and postmodernism. So we should ask whether decolonisation discourse does not create a mythical opponent by fighting ideologies of a different age and epoch that no longer enjoys much public, academic or scientific standing. Has postmodernist discourse not overtaken and overhauled Western modernism? Does contemporary Western thought not present a totally different rational apparatus than the one that Mbembe describes as accepting colonialism as normal, detaching the knower from the known, and dividing mind and world, reason and nature (2015a)? I believe this is the case. Modern Western thought has entered an age of 'extraordinary pluralism', the rigid epistemological undertakings of enlightenment rationality have made way for epistemological approaches that are porous, hybrid and almost relativistic in nature, and the public square in Western 
democracies are increasingly characterised by a wide range of moral commitments (see Gregory 2012:4).

Another disturbing feature of decolonisation discourse is its tendency to insulate itself against external criticism. The notion of 'lived experience' is often misused in this regard. Although knowledge generation and the setting up of institutions are closely related to our experiences, 'lived experience', if treated as a holy space, can also be used to close off debate with the 'others'. Eloff (2017:24) rightly criticises the argument of some 'lived reality' proponents that the personal experiences, sensations and rage of some cannot be questioned by others and that the way I am 'packaging' my experiences and stories cannot be second-guessed. Obviously, this brings the condition of semper Reformanda into jeopardy. How is social reform and authentic discourse possible if 'outsiders' are not allowed to question my personal experiences and if I am not open to self-correction? Are we then engaging in genuine discourse? Are we not merely creating sacral canons that ought to be protected at all costs?

\section{Egalitarian politics and economics}

Decolonisation discourse propagates an egalitarian and inclusive style of political discourse that upends the hierarchical relations between human beings. Fanon considered politics as a 'liturgical act' that strives for consensus and inclusion, rather than an administrative exercise that exerts managerial or technical power (Gibson 2017:594). Decolonisation philosophers therefore emphasise the need for communal and grassroots level participation in decision-making processes. As inclusive decision-making is important to proponents of decolonisation, they tend to be critical of Eurocentric human rights discourses that present their articulations of rights as objective and universally valid (see Zembylas 2017:489). The question they pose is whether Western human rights discourses do not perpetuate colonial thinking and practices by assuming that their conceptions of fundamental rights are inspired by universal and neutral human values? The objection levelled is that rights discourses are always culturally and historically constructed and that no rights frameworks can claim for itself a universal status (see Zembylas 2017:490). In this regard, the question naturally arises whether the drafters of the South African Constitution did not uncritically adopt a Western informed human rights discourse without realising that many of these concepts are foreign to an African worldview. Conversely, it seems implausible to deny the Western intellectual tradition's impact on human civilisation or to dispense totally with the conceptual frameworks it developed. Mungwini (2017:525) rightly notes that the enlightenment produced key political concepts such as rights, individual personhood, dignity, equality and freedom that political, academic and legal discourse cannot help but to invoke. We simply cannot escape using certain norms and principles as universal premises. Ironically, while the decolonisation narrative rejects the notion of universal valid knowledge and principles, it simultaneously demands the radical transformation of
South African society according to 'universalist' notions of what it means to be African.

When it comes to economics, decolonisation discourse places much emphasis on the necessity of upending oppressive economic systems, as racial oppression is seen as intertwined with economic exploitation. Capitalism is viewed with particular aversion, because it represents a 'whiteness' that maximises white privilege though privatisation and the offshoring of assets (see Mbembe 2015b). Economic activities in Africa, so it is argued, serve the needs of the developed west, while Africans are prevented from being the prime beneficiaries of African economic activities (see Mungwini 2016:528). Decolonisation philosophers insist that postcolonial African states ought to be given their rightful place within the global political system and that international trade must be based on fair rules. Socialism is presented as the 'antidote' to capitalism (see Johnson 2013:56). During the \#FeesMustFall protests, student activists made the argument that the South African economy is white-dominated and that there is a collusion between the State and the so-called white monopoly capital (see Gibson 2017:585). The solution offered by students was that the State should engage in a massive redistribution of wealth in South Africa.

How shall we evaluate the political and economic theory of decolonisation theory in terms of the grammar proposed earlier? For a start, mantras such as inclusivity, equality and participatory decision-making should not blind us to the extremist solutions that some, if not most, decolonisation thinkers offer when it comes to politics and economics. Decolonisation, after all, is, in the words of Mbembe (2015a) 'a theory of self-ownership' whereby Africans take back from others 'a bundle of innate rights, capabilities and claims'. Stated differently, decolonisation discourse prides itself on promoting inclusivity and encouraging participatory decision processes, but how tolerant is it when it comes to the voices of outsiders and opponents? While moderate decolonisation philosophers encourage peaceful change through dialogue, the militant brand argues that an equal society can only be achieved through radical transformation and, according to Fanon, even violence if required (1964:36). In fact, the goal of decolonisation, according to Fanon (1967:35), is the 'replacement of a certain species of men by another species of men'. Society cannot be turned upside down without one being prepared to overcome all obstacles with any means available (1967:36). This entails, according to Fanon, that the 'native who decides to put the programme into practice and to become its moving force, is ready for violence at all times' (1967:36). However, the conditions set out earlier for a grammar of peaceful coexistence rules out the possibility of using violence to resolve social conflicts or disrupt social cohesion. Groups that see violence as a means to an end are de facto awarding their own views an ultimate status.

\section{Final remarks}

Decolonisation philosophy's endeavour to impose a collective African national identity on all sectors of society through 
politically and legally enforced processes of decolonisation seems to be highly questionable. Militant strands of decolonisation discourse indeed run the serious risk of manufacturing yet another grand metanarrative that claims to know exactly what the common good entails and that attempts to impose itself on all spheres of society through coercive disruptive means. In this article, I have argued that we should refrain from framing collective ideals of nationhood and social identity. Collective national ideals are not plausible, nor enforceable, within a pluralist society as diverse as South Africa. More would be gained by seeking a basic grammar for peaceful coexistence that sets the parameters for meaningful and constructive social discourse.

The study found that various elements of decolonisation discourse do not satisfy the basic conditions for a grammar of peaceful coexistence that are based on the principles of the universal dignity of all people, the symbiotic and associational nature of human existence, the significance of truth-seeking and the imperative for continuous social reform and selfcorrection. Concerns were raised about the militant strand's propagation of social change through violence, its tendency to insulate itself against external criticism, the factual credibility of its conceptual discourse and the tendency to use white and/or black metaphors in a binary and racial manner. Conversely, decolonisation discourse, especially the moderate brand, makes an important contribution to social discourse by seeking social reform in a highly unequal society. Decolonisation discourse confronts us with inconvenient truths that many do not want to hear, and it illuminates the various facets of the afflictions, adversities and struggles that Africans experience. This is the reason why moderate decolonisation discourse has an important role to play in the South African public realm. Yet, no discourse has an inalienable and innate right to be accepted as valid or meaningful, and all discourses have the duty to cleanse themselves from deviant and militant tendencies.

\section{Acknowledgements \\ Competing interests}

The author declares that he has no financial or personal relationships which may have inappropriately influenced him in writing this article.

\section{References}

Althusius, J., 1964, Politica, transl. and edited F.S. Carney, Liberty Fund, Indianapolis, IN. Ansell, A.E., 2004, 'Two nations of discourse: Mapping racial ideologies in postapartheid South Africa', Politicon 31(1), 3-26. https://doi.org/10.1080/02589340 410001690783

Brunsdon, A., 2017, '\#MisconstruedldentitiesMustFall: Collective identity formation in the current South African context: A practical theological perspective', HTS Teologiese Studies/Theological Studies 73(2), a3822. https://doi.org/10.4102/hts,v73i2.3822
Calvin, J., 1847, Commentary on the Gospel According to John, vol. 1, transl. W. Pringle, Calvin Translation Society, Edinburgh.

Calvin, J., 2009 [1559], Institutes of the Christian Religion, transl. H. Beveridge, Henrickson Publishers, Peabody, MA.

Carman, M., 2016, 'A defence of Wiredu's project of decolonization', South African Journal of Philosophy 35(2), 235-248. https://doi.org/10.1080/02580136.2016.1 176349

Eloff, T., 2017, 'The historical and recent socio-political context for considering racism and related concepts in South Africa', in J.A. Durandt, J.M. Vorster \& N. Vorster (eds.), Togetherness in South Africa. Religious perspectives on racism, xenophobia and economic inequality, pp. 1-28, AOSIS, Cape Town. https://doi.org/10.4102/ aosis.2017.tsa49.02

Etieyibo, E., 2016, 'Why ought the philosophy curriculum in universities in Africa be Africanised?', South African Journal of Philosophy 35(4), 404-417. https://doi.org /10.1080/02580136.2016.1242208

Fanon, F., 1964, Toward the African revolution, Grove Press, New York.

Fanon, F., 1967, Black skin, white masks, transl. C.L. Markmann, Grove Press, New York.

Fanon, F., 2004, The wretched of the earth, transl. R. Philcox, Grove Press, New York.

Gibson, N.C., 2008, 'Upright and free: Fanon in South Africa, from Biko to the shackdwellers' movement (Abahlali baseMjondolo)', Social Identities 14(6), 683-715. https://doi.org/10.1080/13504630802462802

Gibson, N.C., 2017, 'The specter of Fanon: The student movements and the rationality of revolt in South Africa', Social Identities 23(5), 579-599. https://doi.org/10.1080 /13504630.2016.1219123

Gregory, B.S., 2012, The unintended reformation. How a religious revolution secularized society, Cambridge Press, MA.

Haffajee, F., 2015, What if there were no whites in South Africa? Picador Africa, Johannesburg.

Higgs, P., 2012, 'African philosophy and the decolonization of education in Africa: Some critical reflections', Educational Philosophy and Theory 44(Suppl 2), 37-55. https://doi.org/10.1111/j.1469-5812.2011.00794x

Johnson, D., 2013, 'Fanon's travels in postcolonial theory and post-apartheid politics', College Literature: A Journal of Critical Literary Studies 40(2), 52-80. https://doi. org/10.1353/lit.2013.0012

Luckett, C., 2016, 'Curriculum contestation in a post-colonial context: A view from the South', Teaching in Higher Education 21(4), 415-428. https://doi.org/10.1080/13 562517.2016.1155547

Mbembe, A., 2015a, Decolonising knowledge and the question of the archive, viewed 26 November 2017, from http://wiser.wits.ac.za/system/files/achille

Mbembe, A., 2015b, 'Achille Mbembe on the state of South African political life', viewed 26 November 2017, from http://africasacountry.com/2015/09/achillembembe-on-the-state-of-south-african-politics

Mungwini, P., 2016, 'The question of recentring Africa: Thoughts and issues from the global South', South African Journal of Philosophy 35(4), 523-536. https://doi.org /10.1080/02580136.2016.1245554

Ndlovu-Gatsheni, S.J., 2013, 'The entrapment of Africa within the global colonial matrices of power. Eurocentrism, coloniality and de-imperialization in the twenty-first century', Journal of Developing Sciences 29(4), 331-353. https://doi. org/10.1177/0169796X13503195

Nhemachena, A., Mlambo, N. \& Kaundja, M., 2016, 'The notion of the "field" and the practices of researching and writing Africa: Towards decolonial praxis', Africology: The Journal of Pan African Studies 9(7), 15-36.

Ossewaarde, M.R.R., 2007, 'Three rival versions of political enquiry: Althusius and the concept of sphere sovereignty', The Monist 90(1), 106-125. https://doi. org $/ 10.5840 /$ monist20079016

Smit, D., 2017, 'Religion and civil society in "South Africa"? Searching for a grammar for life together', in M. Welker, N. Koopman \& J.M. Vorster (eds.), Church and civil society. German and South African perspectives, pp. 34-63, Sun Press, Society. German.

Van der Westhuizen, M., Gruel, T. \& Beukes, J.W., 2017, 'Are we hearing the voices? Africanisation as part of community development', HTS Teologiese Studies/ Theological Studies 73(3), 4512. https://doi.org/10.4102/hts.v73i34512

Vorster, N., 2017, 'Distorted racial identities in post-apartheid South Africa: A reformed perspective on constructing authentic identities in South Africa', in J.A. Durandt, J.M. Vorster \& N. Vorster (eds.), Togetherness in South Africa. Religious perspectives on racism, xenophobia and economic inequality, pp. 29-58, AOSIS, Cape Town. https://doi.org/10.4102/aosis.2017.tsa49.02

Wisker, G., 2007, Key concepts in post-colonial literature, Palgrave MacMillan, London.

Zembylas, M., 2017, 'Re-contextualising human rights education: Some decolonial strategies and pedagogical/curricular possibilities', Pedagogy, Culture and Society 25(4), 487-499. https://doi.org/10.1080/14681366.2017.1281834 